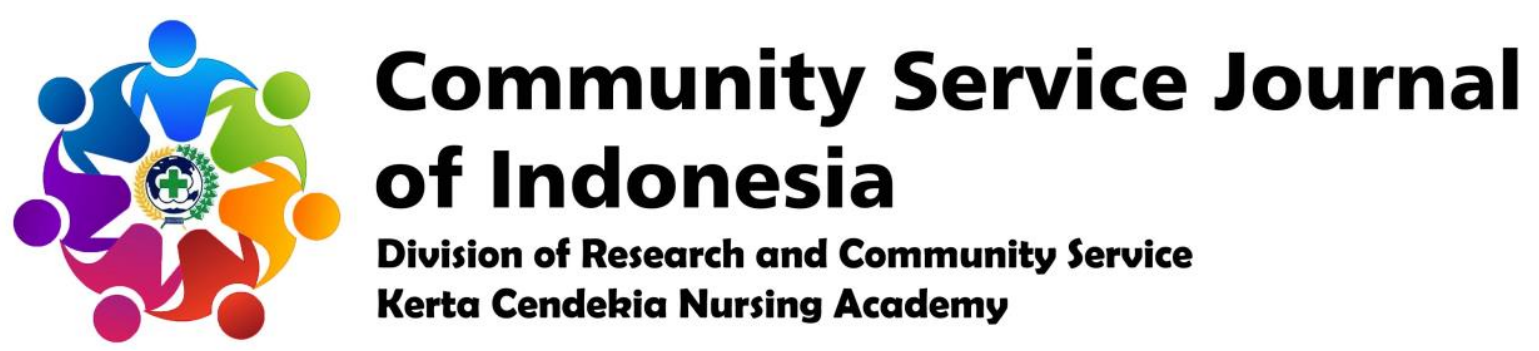

https://ejournal-kertacendekia.id/index.php/csji/index

Community Service Journal of Indonesia 1 (2) (2019): 21-24

Doi: https://doi.org/10.36720/csji.v1i2.133

\title{
IMPROVING KNOWLEDGE OF ADOLESCENT WOMEN ABOUT MENSTRUATION THROUGH HEALTH PROMOTION
}

\author{
Marlita Dewi Lestari ${ }^{1}$, Alya Ainurokhmah ${ }^{2}$, Berta Lisna Suruklusy ${ }^{2}$, Diah Rahayu \\ Ningsih $^{2}$, Khoirul Anwar ${ }^{2}$, Putri Novia ${ }^{2}$, Riza Ismi Dwi Novalia ${ }^{2}$, Sri Wahyuni ${ }^{2}$
}

${ }^{1}$ Lecturer of Kerta Cendekia Nursing Academy, Sidoarjo

${ }^{2}$ Student of Kerta Cendekia Nursing Academy, Sidoarjo

\begin{abstract}
Menstrual Health Promotion Activities for Adolescent Women at the $2^{\text {nd }}$ Junior High School of Buduran, Sidoarjo is a form of community service in the form of counseling aimed at growing and enhancing healthy behavior in adolescents, especially in recognizing the phase of menstruation in adolescent women. The implementation of these activities on December 4, 2018 took place at the $2^{\text {nd }}$ Junior High School of Buduran, Sidoarjo. The target is 7 th grade students of the $2^{\text {nd }}$ Junior High School of Buduran, Sidoarjo. Before the activity is carried out, there is a process of compiling the activity for 3 weeks before the activity is carried out, starting from the selection of health counseling materials to the submission of licensing to the relevant parties. As an evaluation, the activity was attended by 44 students and 1 teacher, participants participated in the activity with enthusiasm and conducive, the activity can be carried out on time smoothly.
\end{abstract}

Keywords: Women's youth knowledge, health promotion, menstruation.

\section{INTRODUCTION}

Menstruation refers to the periodic removal of blood and body cells from the vagina that originate from the uterine lining of women. Menstruation begins at puberty and marks a woman's ability to conceive a child, although other health factors may limit this capacity. Menstruation usually starts between the ages of 10 and 16 years, depending on various factors, including women's health, nutritional status, and body weight relative to height. Menstruation lasts about once a month until women reach the age of 45 - 50 years, again depending on 
health and other influences. The end of a woman's ability to menstruate is called menopause and marks the end of a woman's pregnancy. The average length of a menstrual cycle is 28 days, but ranges from 21 to 40 days. The length of the cycle can vary in one woman during different times. in her life, and even from month to month depends on various things, including the woman's physical, emotional, and nutritional health.

Menstruation is part of a regular process that prepares a woman's body every month for pregnancy. This cycle involves several stages that are controlled by the interaction of hormones secreted by the hypothalamus, the pituitary gland, and ovaries. At the beginning of the cycle, the lining of the uterine cells begins to develop and thicken. This layer acts as a support for the growing fetus when the woman is pregnant. The hormone signals the egg in the ovary to begin to develop. Not long after, an egg is released from the ovary woman and begins to move towards the Falopii tube continuing to the uterus. If the egg is not fertilized by sperm during intercourse (or during artificial insemination), the lining of the uterus will separate from the uterine wall and begin to decay and will be expelled through the vagina. Periods of blood loss, known as menstrual periods (or menses, or menstruation), last for three to seven days. If a woman becomes pregnant, her monthly periods will stop. Therefore, the disappearance of monthly menstruation is a sign (though not always) that a woman is pregnant. Pregnancy can be confirmed by a simple blood test.

\section{OBJECTIVES}

General Purpose

After counseling the students on $7^{\text {th }}$ grade of the $2^{\text {nd }}$ Junior High School of Buduran, Sidoarjo is expected to be able to understand about menstruation in adolescent women.

\section{Special Purpose}

After taking health promotion measures, it is expected that the $7^{\text {th }}$ grade students of the $2^{\text {nd }}$ Junior High School of Buduran, Sidoarjo can be:

1. Able to know the definition of menstruation on the adolescent women.

2. Able to know signs of menstruation will come soon.

3. Able to know the meaning of the colors of menstrual blood.

4. Able to know how to deal with menstrual pain.

5. Able to know signs of menstruation that is not normal.

6. Able to know types of menstruation.

\section{PLAN OF ACTION}

Strategy Plan

The strategy plan implemented, including:

1. Coordinate with the principal of the $2^{\text {nd }}$ Junior High School of Buduran, Sidoarjo to apply for permission to carry out health education or counseling as an activity of the nursing program and to help provide guidance to the $7^{\text {th }}$ grade students of the $2^{\text {nd }}$ Junior High School of Buduran, Sidoarjo.

2. Establish students in the implementation of health education or counseling to know about menstruation.

3. Contract time with the $7^{\text {th }}$ grade female students at the $2^{\text {nd }}$ Junior High School of Buduran, Sidoarjo. 
4. Provide health promotion about menstruation .

\section{Implementation}

Actions taken in the implementation of these activities, including:

1. Contacted the principal of the $2^{\text {nd }}$ Junior High School of Buduran, Sidoarjo to request permission for activities and gather the $7^{\text {th }}$ grade students of the $2^{\text {nd }}$ Junior High School of Buduran, Sidoarjo.

2. Prepare a place and counseling media.

3. The $7^{\text {th }}$ grade female students at the $2^{\text {nd }}$ Junior High School of Buduran, Sidoarjo received extension materials.

\section{Setting}

This activity was carried out at the $2^{\text {nd }}$ Junior High School of Buduran, Sidoarjo.

Target

Target in this activity is all of the $7^{\text {th }}$ grade female students at the $2^{\text {nd }}$ Junior High School of Buduran, Sidoarjo.

\section{RESULTS AND DISCUSSION}

The activity starts at 10:00 WIB and ends at 10:45 WIB, the time of health promotion according to planning. Activities carried out at the $2^{\text {nd }}$ Junior High School of Buduran, Sidoarjo according to the agreement.

The participants who attended were 44 students from the $7^{\text {th }}$ grade at the $2^{\text {nd }}$ Junior High School of Buduran, Sidoarjo along with 1 teacher. Participants seemed conducive and cooperative in the extension activities. $80 \%$ of participants can mention the meaning of menstruation. $75 \%$ of participants can mention signs of menstruation will come soon, signs of menstruation that is not normal, and the meaning of the colors of menstrual blood.
$90 \%$ of participants can mention how to deal with menstrual pain. As many as $80 \%$ of participants can mention types of menstruation.

Activities in the form of health promotion, discussion, question and answer, and distribution of leaflets about menstruation.

The equipment used during the discussion was laptops, power points, videos, and leaflets. The use of very communicative and applicative language in delivering health education, students respond quite well to what has been delivered by students.

Teacher of the $2^{\text {nd }}$ Junior High School of Buduran, Sidoarjo was very enthusiastic and worked very well during the extension.

\section{CONCLUSION}

Improvement of knowledge of the $2^{\text {nd }}$ Junior High School of Buduran, Sidoarjo through health promotion was considered quite successful because almost all students were able to mention the definition of menstruation on the adolescent women (80\%), mentioning the signs of menstruation will come soon, signs of menstruation that is not normal, and the meaning of the colors of menstrual blood (75\%), mentioning how to deal with menstrual pain (90\%), and being able to know types of menstruation $(80 \%)$.

\section{REFERENCES}

Affandi, Biran. (1996). Gangguan Haid pada Remaja dan Dewasa. Jakarta: Fakultas Kedokteran Universitas Indonesia.

Burns, August, dkk. (2000). Pemberdayaan Wanita dalam Bidang Kesehatan. Yogyakarta: Yayasan Essentia Medica. 
Masland, Robert, dkk. (2004). Apa yang Ingin Diketahui Remaja tentang Seks. Jakarta: Bumi Aksara.

Shreeve, Caroline. (1993). Sindrom Pramenstruasi. Jakarta: Arcan Penerbit Umum.

Tan, Anthony. (2002). Wanita dan Nutrisi. Jakarta: Bumi Aksara

Werner, David, dkk. (1999). Apa Yang Anda Kerjakan Bila Tidak Ada Dokter. Yogyakarta: Yayasan Essentia Medica dan Andi Offset.

Wiknjosastro, Hanifa. (2005). Ilmu Kandungan. Jakarta: Yayasan Bina Pustaka Sarwono Prawiroharjo.

Winiastri, Virnye, dkk. (2002). Pengalaman Materi Membantu Remaja Mengatasi Dirinya. Jakarta: Deputi Bidang KB dan Kespro BKKBN.

Zein, Asmar Yetty, dkk. (2005). Psikologi Ibu dan Anak. Yogyakarta: Fitramaya. 